\title{
DRIVING THE GIFT HOME
}

\section{Aaron Mills*}

In reflecting on the relationship between ongoing Canadian colonialism and sacred indigenous spaces, the author considers different conceptions of constitutionalism and of law from the location of Gaamitigomishkag, a sacred site for four Anishinaabe communities (including the author's) in the Boundary Waters area of Treaty \#3. The inquiry is framed by the author's relationship with his grandmother. In the first section he recalls what it was like learning to learn Anishinaabe law from her. He invites his readers to join him in shifting their focus from what to how they learn something (perhaps radically) new. In the second section he shares an anecdote about learning from his grandmother on one particular summer day at Gaamitigomishkag. In the third section, he challenges readers to deploy the interrogative shift from what to how through a narrative that begins to disclose structural differences between Canadian and Anishinaabe constitutionalisms, and thus, their respective systems of law.

Given the narrative form of much of this article, readers have to work for their meanings. Each arc in the third section's narrative begins at Gaamitigomishkag, but discloses very different ways that peoples might constitute themselves as political community in, near and through it. A critical question the article poses is not what, but rather how should one think about community in this space? The article ends in the present where Canadian constitutionalism has been smashed on top of Anishinaabe constitutionalism. The author is left at Gaamitigomishkag reflecting on which community(ies) he belongs to. He invites the reader to consider whether he decides.

Dans le cadre de ses réflexions sur la relation entre le colonialisme canadien qui se poursuit et les espaces autochtones sacrés, l'auteur examine diverses conceptions du constitutionnalisme et du droit depuis l'emplacement de "Gaamitigomishkag », qui est un site sacré pour quatre collectivités anishinaabe de la région du Traité $n^{o} 3$ relatif aux eaux limitrophes. L'auteur mène son analyse autour de sa relation avec sa grand-mère. Dans la première section, il explique à quoi ressemblait l'apprentissage de la loi anishinaabe auprès d'elle. Il demande aux lecteurs de modifier radicalement leur approche et de mettre l'accent, comme il l'a fait, sur la méthode d'apprentissage plutôt que sur l'objet. Dans la deuxième section, il raconte une anecdote au sujet de la leçon apprise de sa grand-mère un jour d'été à Gaamitigomishkag. Dans la troisième section (qui est aussi la plus longue), il demande à nouveau aux lecteurs de passer du quoi au comment au moyen d'un récit qui fait ressortir les différences structurelles entre les constitutionnalismes du Canada et de la Nation anishinaabe et, par conséquent, leurs systèmes de droit respectifs.

Étant donné qu'une bonne partie de l'article est présentée sous forme de récit, les lecteurs doivent déployer des efforts pour trouver le sens des messages qui y sont exprimés. Chaque arc du récit débute à Gaamitigomishkag, mais révèle des façons bien 
différentes dont les peuples peuvent se constituer en communauté politique à l'intérieur et à proximité de cet arc. L'auteur cherche à savoir non pas à quoi, mais plutôt comment réfléchir dans cet espace. L'article se termine à l'époque actuelle, où le constitutionnalisme canadien est substitué à celui de la Nation anishinaabeg. L'auteur se trouve alors à Gaamitigomishkag et cherche à savoir à quelle collectivité il appartient. Il invite le lecteur à se demander si une décision est effectivement prise à ce sujet.

This is how I remember it, how I came to be driving the gift home one morning in late August. I couldn't recommend betting on the truth of it though. Better to discover your own as you travel through the words. For what it's worth, I was once told that the trick of the truth is to abandon what for how and I've found that's proven true.

I'm one of the many who grew up away from his or her reserve (Couchiching First Nation) and away from Anishinaabe teachers. I mention this because it's relevant to my aim here, not because I feel at all sorry for myself. ${ }^{1}$ This happened for the usual reason this happens: because of how colonial violence

* I'm a Bear Clan Anishinaabe from Couchiching First Nation, Treaty \#3 Territory and from North Bay, Robinson-Huron Treaty Territory. I'm grateful to the Trudeau Foundation and to Vanier Canada for their support. I'm so grateful to nokomis, Bessie Mainville, of Couchiching First Nation for all that she's given me and for her desire to help the people. She's eighty-one years old and a tower of power. I also recognize Keith Cherry for helpful comments on a draft.

I have four preliminary notes. First, I've run a certain risk in this article, having chosen to engage with the sacred in an often jocular work. I believe Creator has a tremendous sense of humour and that the sacred not only admits but also invites the ridiculous alongside the reflective. Respect is a matter of discerning when to be which, not a slavish adherence to the latter. I would suggest that the Windigokaan (sacred clown or contrarian) society exemplifies this reality of Anishinaabe lifeworld. But I accept that diversity of opinion about what it means to respectfully engage the sacred is vast. I offer this small slice of my view so that even if yours is quite different, you'll see that I haven't been thoughtless in proceeding as I have. Finally, although I claim all responsibility for any mistakes, I engaged nokomis with my plan for the article and with the article itself.

Second, one of the sacred things I speak about in this chapter is an excavated burial mound. There are four communities with ethical stakes in, knowledge of, and responsibilities for this sacred site: Couchiching, Mitaanjigamiing, Naicatchewenin, and Nigigoonsiminikaaning First Nations. What I say reflects only my own research and what nokomis and one other elder have shared with me; I haven't engaged with oral tradition from all four communities. Clearly then there's much that I don't know and I don't mean to speak in too strong a way. I would ask that in referencing this work, please don't treat what I say here as authoritative but, rather, just as my understanding. Others carry additional knowledge and their contributions are important.

Third, a caution: it would be a serious error to deploy my engagement with the sacred here in an effort to argue categorically or even generally that it's fine for academics to engage with the Indigenous sacred, however or for whatever purposes they wish. My willingness to do so in this instance turns on my relationship with the sacred things discussed. Even at that, two of my elders suggested I might make one change, which I did.

Finally, the majority of this article takes the form of a story, which is only partially offset from the rest of the article. This is deliberate and presents an opportunity for a different (and perhaps unfamiliar and even disorienting) kind of learning. Some readers may need to struggle with the form of the piece in order to find value in its substance. If this is your experience, reflecting on why this is so may prove more useful than anything the story actually says. Perhaps equally challenging, in keeping with Anishinaabe narrative traditions, I decline to reduce the narrative to express normative content. Our stories aren't like Aesop's Fables. The meanings are often ambiguous, and even when they're seemingly clear, as my opening paragraph invites, they require your own articulation (time and again). That said, I have a critically important qualification. The inherent interpretive subjectivity I'm describing isn't postmodern (I'd triple underline that if I could). Especially for a class of stories called aadizookaanan (which this is not), interpretive error is a 
impacted my parents (first one and then the other). As a kid, I came to Couchiching most summers but always as a visitor. For nearly a decade now, I've been coming to ground myself: to learn, give, and grow. In 2015, I moved here. As the years stack like wood, I've been building relationships with people, land, and stories and not just at Couchiching but also in other nearby Anishinaabe communities and out on our traditional territory. By this point, I can say I've given much of my life to learning about our traditional law and governance and the view of political community and of freedom that inspires them. Our traditional law and governance have always remained the focus of my attention because I believe they're the best response to ongoing colonialism, the root cause of Indigenous suffering in Canada. ${ }^{2}$

Especially in the early days, my learning rarely went as planned. I blundered often, having come with good intentions aplenty but little real understanding (such as coming with too clear a plan). Perhaps most important, I came with the wrong kind of humility. I knew I had everything to learn. I didn't know that I didn't know what learning is. I had to learn how to learn and I clued into this insight only with the support and tremendous patience of friends and kind teachers in three different communities (Couchiching, Manitou Rapids, and Mitaanjigamiing First Nations). ${ }^{3}$ My favourite example: nokomis (my grandmother, in Anishinaabemowin) had been sharing teachings on our traditional law with me for two years while I patiently waited for her to get started. One day, I thought, I'll be ready and she'll begin. But she began straightaway. The trouble was that without concepts like "rights" and "duties" in her teachings, the law got lost in the words. Hearing without listening, I think is how people talk about this, or perhaps I've got it backwards. I'm still amazed by her kindness as I slowly learned to learn. Nokomis is my most influential teacher. The time, love, and patience she's put into sharing with me have transformed how I see myself, others, and the world that holds us. She shifted my relationship with the world from a structure of expectations about what I may and may not do to a structure of relationships concerned with who I am and how I should be.

very real possibility. Saying that a story is incomplete without a listener/reader isn't tantamount to saying that anything goes, that it's all discursive play. Rather, while aadizookaanan are constantly changing through time and space, to remain aadizookaanan all of that interpretation happens within the overarching ontological, cosmological, and epistemological framework of Anishinaabe lifeworld, in which persons are interdependent (a category of personhood distinct from, not a specification of, either autonomy or heteronomy), the universe is a unity of gifts, and freedom exists only with and through others, including non-human others. While the story I offer here isn't an aadizookaan, trying to read it with this in mind may prove helpful.

1 In an obvious sense, this is regrettable: I'm forever changed for having grown up elsewhere. But I'm not unfortunate. I see myself as the extremely fortunate beneficiary of permission (Anishinaabe communities' and my own) to act on my desire to learn Anishinaabe ways of being (inaadiziwin) and knowing (gikendaasowin). For sad but compelling reasons, had I grown up on the rez I may not have had this permission or, having it, may not have used it. One of my most surprising discoveries has been that for all the disadvantages that attend the pursuit of Indigenous lifeways while growing up and/or living off-reserve, there can be a strange kind of privilege too.

2 I develop this argument primarily in Aaron Mills, "Rooted Constitutionalism: Growing Political Community" in Michael Asch, John Borrows \& James Tully, eds, Resurgence and Reconciliation (Toronto: University of Toronto Press) [forthcoming] but also in Aaron Mills, "What Is a Treaty? On Contract and Mutual Aid" in John Borrows \& Michael Coyle, eds, The Right $(s)$ Relationship: Reimagining the Implementation of Historical Treaties (Toronto: University of Toronto Press) [forthcoming].

3 I now know an aadizookaan about learning to learn. It comes from Randy Councillor, who was a storykeeper from Naicatchewenin First Nation, across Rainy Lake from Couchiching: Randy Councillor and Art Przybilla, "Nanabozho Learns" in Ojibwe Tales: Stories of the Ojibwe People (International Falls, MN: Lake States Interpretive Association, 2004) 23. 
This is a remarkable thing, given the litany of errors I mentioned. Here are examples of what I didn't know about how to learn from her. I knew to go with asema (tobacco) but not how or when to offer it, and I had only a thin understanding of what it meant. I didn't know to come with miigiwewin (a gift). I was intimidated the first time she brought out her opwaagan (pipe) because I didn't grow up with opwaaganan and so didn't understand them. I didn't know what (if anything) was expected of me as she prepared and then smoked it. I was afraid of making a mistake and I didn't know I could ask about things I don't know about. Most important, I didn't know that I was the only one made uncomfortable by my lack of knowledge here and that if I'd just relax, I could learn much by listening and watching.

I didn't know that although I speak too, our time together isn't (in a plain sense) a dialogue because most of the time she's sharing and I'm listening and that's exactly as it should be. I didn't know, for instance, that in general I'm not to proceed by asking questions, on risk of impertinence. I didn't know to state what I want to learn about a few days ahead of time because she'll want to reflect and pray on it before answering. Similarly, I didn't understand that rather than presenting her with a slow but progressive line of questioning, she'll just want to hear the one that really matters because she'll decide which details are relevant. I had to slowly learn that a quiet moment isn't an invitation to jump in. After misguided interjections, I realized she probably won't return to what she was thinking about. I had to learn to sit with the silence.

I didn't know that sometimes the things shared indirectly are the most important and need even more careful listening. I didn't know just how careful I needed to be because a gaffe on my part isn't likely to be openly confronted. ${ }^{4}$ I didn't know that things shared with me are always things shared with me, now, and in this place: that they reflect a judgment about what I'm able to hear and what can be said here, today, and in the context of our relationship. I didn't know that a teaching might issue in parts or that later I might understand what was earlier shared in a deeper way. I knew an ethic of reciprocity had to characterize our relationship but didn't know how I could possibly give back, and I thought my giving had to be directly to her. I didn't know I would need to discern unique meanings from common words like "law"; that since English is her second language, I need to listen for meaning; and that over time I'd associate particular meanings with a repertoire of uses of words and phrases unique to her. I could never have imagined the confidence I'd get from nokomis signalling my growth back to me. Finally, I wasn't prepared for my truth to matter to one as knowledgeable as she. I had no idea how much these conversations would also mean to her.

All of which is to say nokomis and I have worked together through countless hours, seasons, and years; through changing circumstances, abilities, and relationships. It's been quite a journey. Although these next five words are a small thing, they're all of it: I'm grateful for the gift.

So: August 2013. It happened like this.

$* * *$

I'm wiping the kitchen table while nokomis pours coffee by the window. She smiles and says she wants to take me to Gaamitigomishkag, the Seven Oaks. I know it's a special site for people at

$4 \quad$ I recall the only time this happened: as we were returning from a visit with Annie Wilson at Manitou Rapids, nokomis told me not to ask other elders about our "law" anymore because that isn't how they talk or think about the thing I want to learn. 
Couchiching and nearby Anishinaabe communities. ${ }^{5}$ She peers out into the thick grey sky, trying to decide if we could beat the coming rain if we left now. It's been pouring for weeks and given what little I already know about Gaamitigomishkag, I'm guessing the rising water is what brought it to her mind. Koojijing Zaaga'igan - now more often called Rainy Lake - washes up against the southern end of her certificate of possession land. It's reaching much higher up the bank than usual this summer. She turns to face me and says she thinks we've got time. I nod and we head out. I drive us past the Catholic Church, Our Lady of Lourdes, and the reserve graveyard; past the NANICOST building (formerly St Margaret's Indian Residential School, which four First Nations, including ours, have repurposed) and the considerable number of expired, ninety-nine-year-lease settler lake homes on the disputed Agency 1 reserve immediately adjacent to us; past the also disputed Point Park until we reach its southern tip, Gaamitigomishkag. ${ }^{6}$ The drive only takes a few minutes from our reserve but you pass through generations of history and ongoing fracture in getting there.

Gaamitigomishkag marks the transition between Koojijing Zaaga'igan and Saagitiwong (Rainy River). Across the water is Ranier, Minnesota. I can see window trim and shingling on individual American houses. We stroll in silence along the edge of where Saagitiwong slides against the land. Soon we arrive where a burial mound used to be (see Figures 1 and 2). Although it's August, there's a snow white rabbit smack in the middle of the former mound site, munching thick grass and following us with one wandering eye. There's a twinkle in it that tugs on my neck hair but nokomis doesn't seem to think anything of this fuzzy one so I let it go and rest my attention on her. I know the story of the burial mound or at least part of it, but I've never before heard her speak of it. ${ }^{7}$ She gazes into the current and begins with rising water. She tells me that the settler people raised the entire lake for their lumber mills, that it rose up and poured over the land. ${ }^{8}$

5 Gaamitigomishkaag forms part of the Agency 1 Reserve, which is held collectively by four Anishinaabe political communities: the Couchiching, Mitaanjigamiing, Naicatchewenin, and Nigigoonsiminikaaning First Nations. The town of Fort Frances claims it for itself.

6 See, for instance, Couchiching FN et al v AG Canada et al, 2014 ONSC 1076.

7 On at least one excavation, bodies were removed. George Bryce, The Mound Builders (Winnipeg: Manitoba Free Press Print, 1885), Manitoba Historical Society, Transactions, Series 1, No 18, at 3, 4, 7. One of the worst things I've heard is that Indian agent R.J.N. Pither dug into it to create a root cellar for himself. This was also written up in W.A. Kenyon, Mounds of Sacred Earth: Burial Mounds of Ontario, Archaeology Monograph 9, Royal Ontario Museum (Toronto: University of Toronto Press, 1986) at 65. Another is that the mound was destroyed in order to convert Gaamitigomishkag into part of a municipal park for Fort Frances. See E Leigh Syms, Aboriginal Mounds in Southern Manitoba: An Evaluative Overview, Manuscript Report Number 323 (Ottawa: Parks Canada, 1978) at 107.

8 The year 1916, in particular, saw horrendous flooding. For the impact on Gaamitigomishkaag, see Ontario Land Surveyor's Description Report, 10 September 1918, Fort Frances, ON, Public Archives of Canada, RG 10, vol 3091, file 282,759 (the section addressing "that part of Pither's Point Park lying south of the Right of Way of the Canadian Northern Railway" refers to Gaamitigomishkag). More generally, the International Joint Commission's report on the flood conditions of 1916 observed that: "Probably the greatest damage by actual erosion occasioned by present water conditions on Rainy Lake has occurred along the Indian reserve fronting on this Lake on the Canadian side, extending from a point about 3 miles above Fort Frances for a distance of probably 2 miles [that is, Couchiching First Nation]. The municipal boundaries of the town extend along the Rainy River to the lake and include Pithers Point, a well-wooded piece of property used as a park. Here also it is believed that damage has been done by flooding, the extent of which, however, can only be determined when the waters recede." Charles A MaGrath and James A Tawney, Report on the Flood Conditions in the Lake of the Woods and Rainy Lake Districts, Minnesota and Ontario; Together with a General Statement of the Water Levels, Interests Involved and Methods of Relief (Washington, DC: Government Printing Office, 


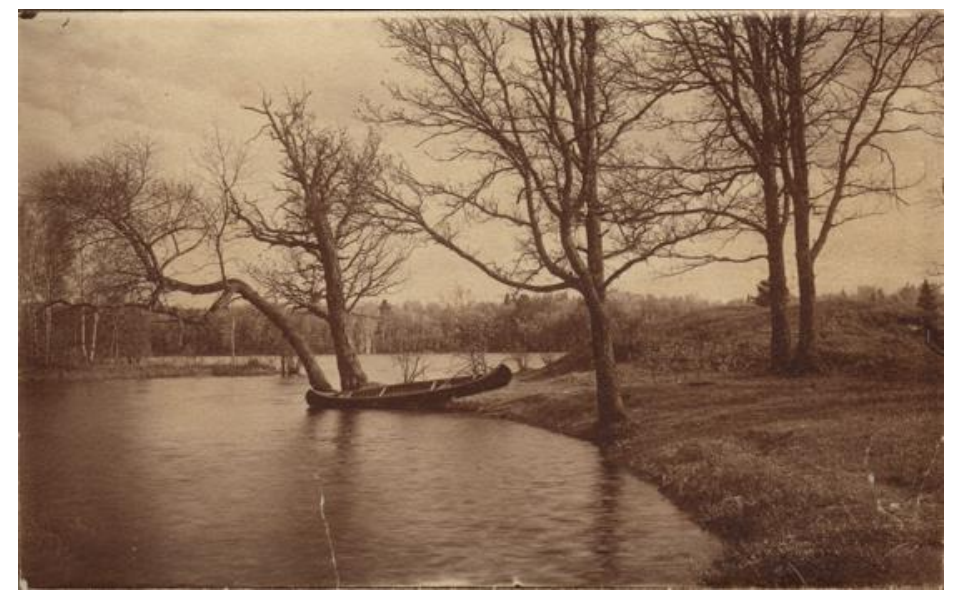

Figure 1: Fort Frances Museum, untitled photograph, 2 September 1918 (Source: Connie Hollands)

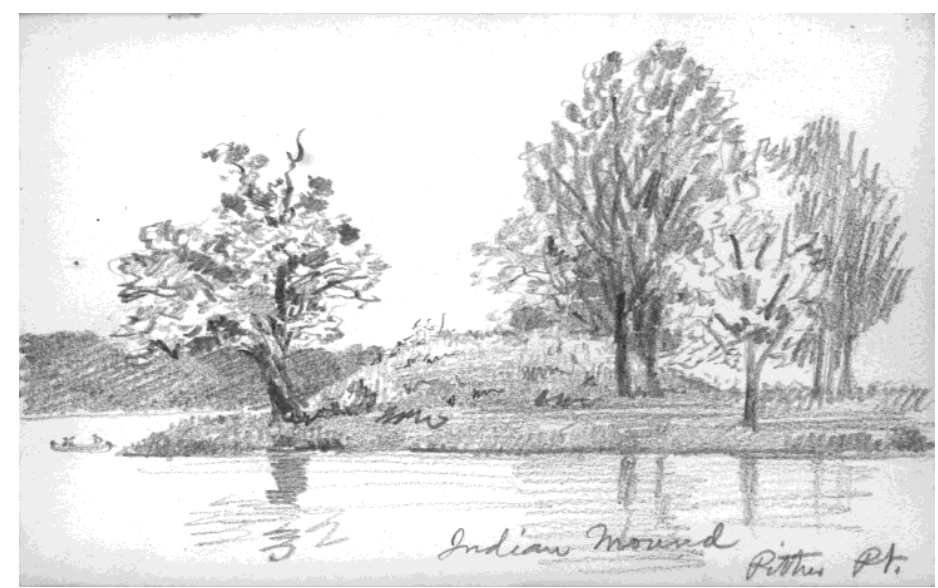

Figure 2: A.P. Coleman, Indian Mound, Pither's Point in Sketchbook 1b, circa 1880, 31 (Source: Victoria University Library (Toronto))

Four-and-a half-kilometres downriver sits a hydroelectric generating station and its dam. The dam also served the original lumber mills and, for more than half a century, has served a modern pulp and paper mill that dominates the skyline. Completed in 1911, the plant generated enough hydroelectric power to run two municipalities for decades: Fort Frances, Ontario, and International Falls, Minnesota. In 1912, a private international bridge was completed, connecting them. While the dam generated

1916) at 6. The report later turns to causes for the flooding. After noting the unusual amount of rainfall, it states: "The situation, however, has unquestionably been aggravated by the system of control that has prevailed, as it must be obvious where controlling dams are operated independently, as is the case on these waters [that is, on Namakan Lake, Rainy Lake, and Lake of the Woods], there must be an absence of uniformity in method, a lack of intelligent cooperation and foresight, resulting in extremes, high or low, developing abnormally; and it is safe to say that if such regulation as the International Joint Commissions is now considering had been in force at the present time, the excessive high water would have been materially checked, if not entirely prevented" (at 7). 
tremendous power for these Canadian and American settler communities and transformed the relationship between the water and the earth, it devastated Anishinaabe communities on Koojijing Zaaga'igan. ${ }^{9}$ Countless animals drowned in the rising water, duck migration stopping points disappeared as bogs turned into bays, and our staple food, manoomin (wild rice), disappeared beneath the waves. In the early twentieth-century flooding, at least some Anishinaabe communities experienced an economic collapse. As land masses became islands and as shores receded, critically important geographic features like sandy beaches used in canoe construction vanished, and place-based spiritual relations were disrupted. Some communities uprooted their existence, relocating each time the water was raised. Survival was precarious because countless fallen trees created a barrier along the shoreline keeping birch bark canoes from landing. The resulting lack of food was dire. ${ }^{10}$

Nokomis stands tall and quiet and much like these remaining firm-rooted trees looking out on the river. A gentle breeze catches her hair and my sleeves. She's thinking about what to say in English, to me, here, at this time. The measure of the decision settles in the lines of her face, the focus of her eyes. Eventually, she raises an arm, gesturing down the river, and I follow her teaching around the bend to where it stops at the hydroelectric station now so visibly marked by the pale blue infrastructure of the mill. With weighted words, she tells me that the ogimaag (leaders) tried so very hard to stop all of that from being built. When settlers built the dam and backed up the river, the rising water swallowed a waterfall (see Figure 3), which is now just current beneath the surface. ${ }^{11}$ It's a sacred site of tremendous significance. " 12 "Kinagego nishwaanajigaate," she recalls hearing the old people explain of this situation: "Everything is being destroyed." 13

9 Data on Rainy Lake water levels through time is available on the Lake of the Woods Control Board's historical charts. Observe the dramatic and seemingly unpredictable control exercised over annual and seasonal variation of Rainy Lake water levels for the first half of the twentieth century (note especially data for 1916 and 1917). Lake of the Woods Control Board, "Historical Graphs," "Rainy Lake," online: <http://www.lwcb.ca/historicalgraphs.html>.

10 Over many years, I've received fairly extensive teachings about this from an Elder from one of these communities who prefers not to be named. I've also reviewed litigation transcripts of Elders' expert testimony directly on these points.

11 In 1872, Major William Francis Butler, a British officer, described the "hollow roar" of the falls as his men paddled towards it from below. WF Butler, The Great Lone Land: A Narrative of Travel and Adventure in the North-West of America, 7th edition (London: Sampson Low, Marston, Low, and Searle, 1875) at 166. There are numerous accounts of its size. The earliest account is from July 1775 and it says forty feet. Alexander Henry, Travels and Adventures in Canada and the Indian Territories between the Years 1760 and 1776, Part I (New York: I Riley, 1809) at 241-242. In the 1860s, Henry Youle Hind and Simon J Dawson both reported a height of $22 \frac{88}{100}$ feet. Henry Youle Hind, Narrative of the Canadian Red River Exploring Expedition of 1857 and of the Assinniboine and Saskatchewan Exploring Expedition of 1858, vol 1 (London: Longman, Green, Longman, and Roberts, 1860) at 81; SJ Dawson, Report on the Line of Route between Lake Superior and the Red River Settlement (Ottawa: Hunter, Rose \& Company, 1868) at 18. In 1917, postflooding, the Ottawa-Washington International Joint Commission on the Lake of the Woods Reference reported a preflooding height of "about 22 feet." International Joint Commission, Final Report of the International Joint Commission on the Lake of the Woods Reference (Washington, DC: Government Printing Office, 1917) at 216.

12 I realize that without explanation, regrettably this says little. This kind of information can't be shared in this way.

13 This is nokomis' own translation. 


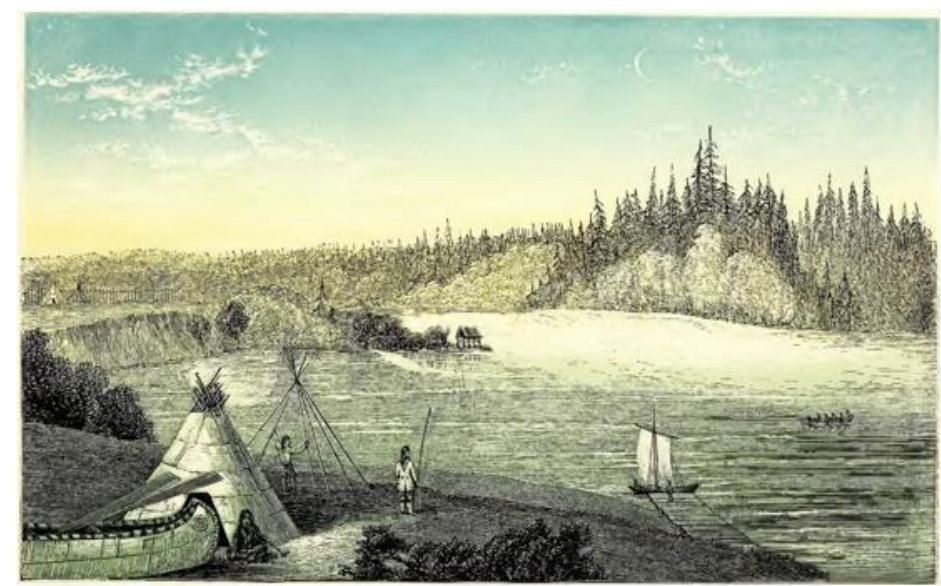

Figure 3: "Falls on Rainy River Opposite Fort Frances" (Henry Youle Hind, Narrative of the Canadian Red River Exploring Expedition of 1857 and of the Assinniboine and Saskatchewan Exploring Expedition of 1858, vol. 1 (London: Spottiswoode and Company, 1860)).

We have two spiritual erasures connected by the same industrial event, the forced raising of the waters. Following nokomis' arm, Saagitiwong connects the site of the former mound and the waterfall downriver. But, overland, the link is starker. Connecting the erasure of one people's way of being and the overwriting by another people's is a strip of pavement. Colonization Road connects Gaamitigomishkag with the town of Fort Frances (see Figure 4), naming the relation at work in these erasures. ${ }^{14}$ The mound's still gone and its absence is still felt. Worse, the Point Park is now claimed by Fort Frances in an ongoing legal proceeding. The waterfall is still buried beneath an artificially raised river. ${ }^{15}$ The impacts are enormous and ongoing for local Anishinaabeg and our non-human relations. These aren't erasures that were completed the moment the Crown asserted sovereignty or as European settlement and indigenous displacement progressed. These erasures are still happening now. They're locations on a road we're still travelling. In fact, overland you can't travel between the reserve and the town without moving through it. Colonialism is a relationship, not a settled historical fact. Hearing nokomis draw out the relationship between these things isn't my introduction to this realization, but having it grounded here, in my community, is an especially powerful way to receive it.

14 Couchiching First Nation community member Ryan McMahon's documentary Colonization Road helpfully draws out this tension. See Colonization Road (Decolonization Road Productions, in association with The Breath Films, 2016).

15 Today, the water level is controlled by the Lake of the Woods Control Board and the inter-jurisdictional Canada-United States legal framework that it implements. No First Nations are members, although they're invited to join in an advisory capacity. See "First Nations and Their First Nation Advisors" at Lake of the Woods Control Board, online:

<http://www.lwcb.ca/BoardDesc/index.html>. However see also Letter from then-Grand Chief / Ogichiidaakwe Diane Kelly of Grand Council Treaty \#3 to International Joint Commission (18 August 2011), online: <http://www.ijc.org/conseil_board/rainy_river_watershed/sites/default/files/18\%2008\%2011\%20GCT3\%20to\%20IJC\% 20Letter\%20regarding\%20Final\%20Report\%20on\%20Watershed\%20Comments\%20and\%20Demands.pdf $>$. 


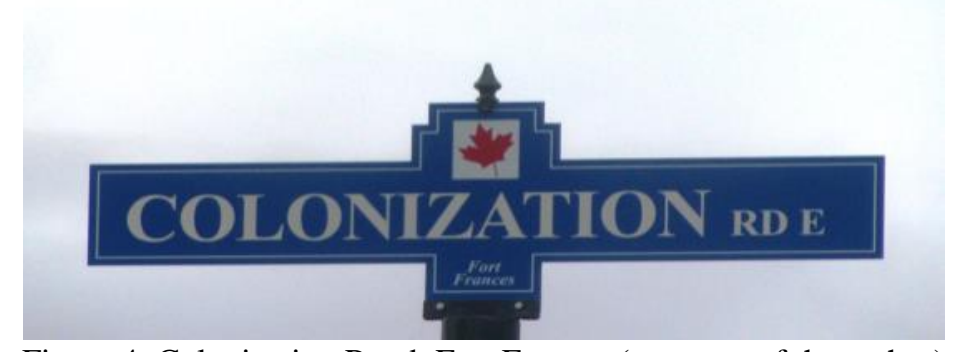

Figure 4: Colonization Road, Fort Frances (courtesy of the author)

And with that thought - my community - my day takes a sudden turn. As if the errant thought were spoken, the white rabbit turns to face me square, stands on his hind quarters, plants hands on hips and challenges, "community: now what do you suppose that is, eh?"

I blink, once, twice.

That rabbit just addressed me. In words. English words. Talking Rabbit cocks his head to one side, his nose furiously atwitch. He takes one step closer and leans in sniffing, sniffing, sniffing. What I have no idea, but he seems to be onto something. From the curl of his lip, I'm guessing it's not good. I suspect the distasteful smell is fear though because I fear I'm just a few wrong moves from tumult. I recall the stories I know. Perhaps fuzzy wuzzy over there is not just unusual; perhaps (this is the fear) he's unique. Perhaps this one teaches but not like nokomis. If this one's unique, in his presence you can quickly find yourself on the wrong end of a story.

"Can't answer eh? Don't worry, I'll just show you. Showing's better anyway," announces Talking Rabbit with a triumphant chirp. "What your community is, I mean."

Please don't, says the worried voice in my head. I'd really rather pass on the rabbit show. Also, this isn't happening.

Talking Rabbit grins my way. Big grin. Smile just about connects his ears. My chin drops to my chest. But far from discouraged by my open lack of enthusiasm, Talking Rabbit seems inspired. He spits out half-chewed grass like confetti and binkies. A second and a third time, he binkies! Fuzzy rabbit bits bounce and pierce grey sky. He's excited about something alright! And now that he's warm, he begins a routine of rabbit stretches, as if preparing for something vigorous. Nokomis tries hard not to giggle. Very hard. Both hands are needed to stifle the rebellious humour from egress - doesn't want to be caught by that one giggling at that one. Which is rather telling about that one, probably confirming my fear.

Talking Rabbit lets out a mountainous rumble of wheezy air as his drawn-out exertions break the lines of his form. Slowly - at first indiscernible but soon unmistakable - that one stretches himself out. Literally. He stretches out his arms, legs, and torso. He stretches chin up and shoulders down 'til he shakes and it looks like his head might pop off from the strain. But it doesn't. Instead, he fills that new space between chin and shoulders with neck. He stretches until he's roughly human in shape. Roughly human: upright; four appendages extending from a central trunk (two out, two down); the lower two 
supporting the ungainly assemblage. The hand paws culminate in five twitchy digits, but he retains his thumper feet and antennae ears in their rabbit entirety. He remains covered in downy fur, and each leg retains a wicked bend at knee and ankle. The final result is wrapped in velvety mink briefs, like He-Man presenting at court, and the transformation is complete.

Talking Rabbit Manshape looks to my grandmother and approaches her, shaking her hand warmly with both of his. "Boozhoo, Bessie." They speak in Anishinaabemowin, and I can only understand bits and pieces of their exchange, but the familiarity between them is clear enough. Not the first time he's come to her perhaps, but I'm guessing it's the first time he's come quite like this. She's not fazed though; not fazed by much, that one.

Now me, I'm fazed. As Talking Rabbit Manshape turns his attention back my way, I open my mouth to speak and find the muscles have all gone slack. All the while smiling at our transformed friend, with delicate but stern fingers nokomis reconnects my lower jaw to my upper. With the gentle clunk of my rejoinder, she tilts her head my way and, though I'm taller, manages to look ever so slightly down on me, emphasizing the stringent V of her brow. Unfortunately for me, just as I'm reminded to be gracious, Talking Rabbit Manshape pushes the issue of his new bearing.

"So?" He pauses, looking at me expectantly. "What do you think?" He looks himself over, admiring first one side, then the other. He tugs on the edges of his dashing mink briefs, nodding with tremendous self-approval. Looks up at me and blinks. I'm carefully - very carefully - considering my miserable options when a sound bursts from my lips, proclaiming itself upon the conversation. I'm as surprised as he by this development. Given its particulars, I don't dare look at nokomis. The sound is just that, a solitary syllable: "Why?" I ask at a quarter my usual speed and quadruple my more habitual surprise. Nokomis bends my finger, pointed squarely at Talking Rabbit Manshape, back into the palm that should've held it. Talking Rabbit Manshape takes two steps forward until the tips of his rabbit toes rest atop my sneakers.

"Isn't it obvious?" he asks, scratching his head.

I shake mine the tiniest bit left and right, almost hoping he won't notice. He does.

"You might be surprised how many Nishnaabs nowadays are discomforted when one rabbit isn't like all the others," he says. "Case in point: talking and shifting. They don't much like that in rabbits." Then gravely, lowering his voice and gaze, "rabbitism's a serious social ill, you realize." He pauses, hoping weight will pile up on those words. I start nodding agreement in support of the desired effect. "They expect me to look and sound just so; it's insufferable." He pauses. "You seemed discomforted. So. I. Transformed. So you wouldn't be discomforted, so we could have a decent conversation without your unseemly rabbitism running roughshod over the journey. Obviously."

"Obviously," I repeat (still nodding). "Apologies."

"Yes, and now as for the matter of these fantastic bottoms, I like to be as aerodynamic as possible when travelling between worlds. It's a major undertaking you know and this one (pointing at himself) likes to conserve energy."

My early trepidation now affixes itself to these suggestive words, "the journey" and "between worlds." "If I may," I seize upon his pause, "about the mention of you travelling between worlds_-"

"I was just coming to that."

"Oh good."

"It's more like 'we' really." 
"It is?"

"Yes, more like exactly."

"I see."

At this point, nokomis leans in and says: "Listen carefully here, noozhishenh." Talking Rabbit Manshape, appreciative of the added importance, clears his throat louder than is necessary: "Yes, you mentioned your community, which raises a problem."

"It does?"

"It does. Problem is there's more than one. Always has been. And they're all different." He picks up a stick and begins to draw in the earthen circle where he's nibbled all the grass away. "Alright, it's like this. There's two council fires and I'm in both of 'em. No, wait." Talking Rabbit Manshape displays sudden alarm upon realizing that he's drawn two boiling pots of rabbit stew. Nokomis again with the giggles.

"No, that's not it. I know: there's two solitudes on Turtle Island and we have to get them talking." Now I'm looking at a picture of two men, arms crossed and backs to one another, who so far as I can tell look the exact same except that one has a stiff upper lip, the other, un crayon moustache. Poised as they are, neither seems all that concerned about responsibility. I'm finding this confusing. Nokomis seems to fare no better.

"No, that's not it either," he mutters. "Ooooh, hey I know. There's two villages and I'm an anthropologist and I'm from one but I'm in the other and now I'm back in my own telling stories about stories because we're self and they're other and always will be because of knowing. Something like that anyway. Gosh, I love stories."

Now I'm looking at a chaos of lines between two villages, but they seem rigid, separating their points of contact as much as they link them. Not sure what those lines represent. I think that all that "story" business means they're supposed to be "communication lines," like in the Woodlands School of Art, but that doesn't explain the apartness. No, that's not it either, I'm not getting it. Talking Rabbit Manshape sees my confusion and frowns, blaming himself. We both sit head on hands for a few moments while nokomis slowly paces circles around us.

"Hey, hey I just remembered!" Talking Rabbit Manshape exclaims all at once. He hops up and scribbles furiously into the earth, this time with too much concentration to talk as he goes. Before many moments, his masterpiece is complete. Nokomis and I take in the finished product: we're looking at a circle filled with pictures. Towards its far left curve is a tree - Canadian maple - standing tall. It looks awfully proud there, but it's all alone in its part of the circle, just floating there disconnected. No ground beneath or sky above. Nothing to either side or in front and no background either. Just that one living tree. On the far right of the circle is a forest so full it pushes into the edges of the arc so that the diverse life within bends into the curve. Talking Rabbit Manshape has drawn different kinds of trees rooted in earth, scraping at clouds, hosting squirrels, butterflies, grubs, and mosses. That's the picture.

Talking Rabbit Manshape claps his hands together sending the dust of failed images flying. "So: there's two kinds of political communities on this land and I - and you - am affected by both of 'em. To understand the situation, we need to visit them. C'mon, let's go!" He grabs my hand and starts to run. Each of his springy steps marks four of mine and I find myself half dragged through Gaamitigomishkag as rabbit feet accelerate over grassy plain, aimed towards the mill. I peek over my shoulder at a fast shrinking nokomis, who cries out in her most matronly voice: "Noozhishenh, where's your helmet???" I 
look feebly to my host who snaps his fingers and -POOF! a cherry red helmet sits snug on my head. There's no way for me to keep up now. I climb onto his back and bury each fist in a clump of rabbit fur. And then with one superhuman leap, he bounds skyward. Nokomis is my loving grandmother, then an arm waving, and then a dot.

"Alright, this is the one about political community," he says as we pass some pelicans. "Our lives today, our stories tomorrow. You'll tell it and it'll be a good one," he assures me. But then suspiciously and with much too much brow: "You're gonna have to tell it properly though." We sail through sky for ages, away from earth, upupup until blue fades to black, and then we drop downdowndown. We crash in a heap.

"Hey, where'd you bring me!" I protest, my helmet covering half my face. Through one eye, I see trees, a lake, and a river. There's something awfully familiar about them.

"Shush, you're gonna wanna be quiet here," he says. "Like a mouse. These are strange ones, these ones - whether through secret machination or confederacy with others, the weakest kill the strongest. Regular-like, happens all the time." Well I don't like the sound of that! "Besides," he says, "didn't anyone teach you how to learn? We need questions. I ask 'em all the time. But the question about questions is how you ask. You wanna learn about community, you better learn to listen and watch." Talking Rabbit Manshape is interrupted by his own idea, which clearly amuses him: "Like you're a giant baby wrapped snug in your tikinaagan."

So that's what I do. For days, months, millennia of Talking Rabbit Manshape time, and what I see is amazing. It starts with people - always alone - fumbling through the wilderness, a tree branch club or filed flint shard in hand. No semblance of togetherness: each soul seems to wander about trying not to find the others, unless by means of banding together, temporarily, to discourage other others from approaching. Paranoia and ubiquitous fear darken the land like clouds. Each person tries to meet all of his or her own needs as though her or she were alone in the universe.

Then one day something fascinating happens. One of these isolated souls risks life and limb to organize a meeting with others because she's had an idea, a big one: she wants to know what would happen if all decide together to have a leader who alone is vested with the power of violence. In such an arrangement, anyone else who acts violently - whether as an initial act or in retaliation (assuming that such distinctions can be established) - would be punished for it. This, she explains, is the magic trick to her proposal: if all agreed to have such a leader and all agreed that he or she alone would punish any transgressor of the rule against violence, then anyone so punished is still free for he's punished under his own agreement, no matter how he might kick and scream at finding himself on the unintended end of it. A leader vested with such a power could take us out of this isolating state of nature and into community, she says, where we would live alongside one another. She asks everyone to imagine what benefits that might bring.

Then explodes countless questions and thought experiments; all manner of what ifs and worries. But against a reality of rampant fear, the bargain is easily struck, and everyone wants in.

So, for a long while, they live as envisioned, thinking life much improved and settling into community. It turns out that the ubiquitous fear of violence was the only thing that kept these nomads roaming aimlessly overland, hunting and gathering. With the cause of trouble taken care of, they prefer to stay put and they began to repurpose the land for agriculture, pushing the tree line ever further away. The exercise of control involved in this transformation soon leads to feelings of attachment, which 
eventually harden and settle as feelings of entitlement. The leader, and through her all others, soon recognizes the land that individuals have transformed as theirs.

But then something unexpected happens: entitlement migrates upwards. The next leader quickly gets comfy with his power. In his lifetime, there's always been a leader. He only knows from stories what it was like in the time before leaders and his imagination isn't very good. As his governance endures, he thinks less of those he exercises leadership for and more of his own desires. He begins to issue rules that serve his own interests, and before long he's changing rules, like desires, at his whimsy. At one point or another, almost every community member is subject to rules (often taxes) reflecting goals they don't share. They feel something awfully important has been violated and that because of it they're no longer free. The mood in the community shifts darkly.

At risk of being killed (by now a common punishment), a group of angry folks holds a clandestine meeting at one of their houses to decide what to do. There's discord and dissension around the table that evening, but all nod agreement on two ideas: on the one hand, they can't do without the leader because otherwise the agreement against violence can't be enforced; on the other, they can't take much more of him drunk on violence and whimsy either. Many ideas are offered, but none bears the whole group's scrutiny.

Now throughout the discussion, a little girl, daughter to the host family, has been listening from around the corner. At last exasperated with what she takes to be the habitual adult foolishness - making simple things complicated - she steps into the light. Her father immediately tells her it's past her bedtime and to go straight to bed. The little girl, often angry with her parents for not having to follow the rules they set for her, plants her feet and asks one very simple question: "Um, excuse me, but why doesn't brave leader hafta follow the rules? Like he's a dad and you're just kids like me or what?"

Silence and mouths agape. Distant crickets.

Well. That small intervention sends murmurs throughout the households that culminate in a roar, and it demands change: the community retains the role of the ruler but decides that rule will no longer be strictly by him, but by laws which he too must follow. There are still the rules he creates and enforces after all, that need is why they have him - but now there will also be higher rules that constrain how he does so. Importantly, some of them will regard how each community member can participate in replacing him.

The community feels it's really coming along now, and a general sense of excitement fills the streets. They have another meeting - happily, open again - to figure out what the higher law should be. But that doesn't prove so easy. While one man says it should reflect his religion, another shouts him down saying his religion is no good; the higher law should instead reflect this second man's culture. A woman shakes her head and says she's worried about what would happen to her and her daughter if either the first man's religion or the second man's culture directed the higher law. She thinks that instead of these huge visions, people should just be kind. The first man lights up at hearing this suggestion because, wouldn't you know it, that's exactly what his religion promotes. You can guess what the second man says. The woman crosses to the other side of the room.

After some of the more obnoxious men are told that louder doesn't mean better, the clash of voices begins to quiet down. That community members hold wild differences of opinion (including on how to generate worthy opinions) eventually dawns over all. The moment serves as a reminder to many of the story about the time before community - nature time - when the aloneness of each was plain to the 
understanding of all. None wants nature time back for the story talks about the lawless fear the state of nature held, but nor is anyone willing to live another's way. So they sit there stuck for a long while.

For a little boy of the host family, too long. Exasperated at having been told one more time that he isn't having dinner until the guests go home, he opts for self-help. Following the family tradition on snacks, he takes out yesterday's leftovers (quiche; there's half left) and calls over his sister. He wishes he didn't have to. He wishes he made the rules. The rules would ignore her. To be sure, the boy begrudges her a half half (the boy doesn't think in quarters). He's a hungry boy and he wants the whole half. But he knows that when she finds out it's gone she'll tell and he'll be denied desert, which is unacceptable. So they play their roles: he cuts, she chooses. And he enjoys every bite of his share. As he swallows down the last of it, he hears his own gulp and it occurs to him that the room has fallen silent. He looks up to find that his seat at the kitchen table has become an impromptu stage: all eyes are on him. His first thought is that he's glad he doesn't have to share with all these other folks. That's his last thought too. He sure likes quiche.

Sipping his juice, the boy walks slowly back to his room, confident because he hasn't broken the rules. As the boy rounds the corner, the adults all seem to have spontaneously had the same novel insight, and the room explodes with chatter. The higher law needs to be formal and limited to matters of procedure - that way everyone, no matter what she thinks, believes or practices, can do so, subject to one firm limit: that she not impact anyone else's ability to think, say, or do differently. Each, as it were, gets an equal share of the community and the procedural higher law makes sure of it.

In the following days and weeks, I notice this has an immediate and significant consequence for how law structures human interaction. The leftovers model, applied to the community, produces a central cleavage between public (everyone's and no one's - that is, neutral - space) and private (each to his or her own space). Governance, through the leader, happens only in public. Beyond matters of community governance, individual persons, families, and voluntary groups express the cacophony of conflicting values and beliefs that characterize their private lives and associations. This is where the first man practises his religion; the second, his culture, and the walkaway woman, kindness. None is satisfied but each thinks himself or herself free.

Well, most folks. Some get confused on the details of how freedom works and try to fill public space with private views. You might think that when this happens, folks would kindly ask the boundarycrosser to please stop. They don't. They shout at him and berate him. The call him stupid and greedy and stupid once more. The gentle ones add that he's misunderstood something rather important about the community's foundation in the higher law, while the excitable ones just tell him he hates freedom. All of which behaviour discloses that community members feel entitled to live under such conditions; entitled because the initial authorization for the entire enterprise of community - the great escape from nature that results in a shared "us" - exists only because each "I" willed it so. And because each "I" is so important, entitlement is the strength of claim that follows from this great, voluntary giving up of unconstrained, private freedom. Laws expounding and policing individual entitlements flowing from the public-private divide (and conditioning behaviour on each side of it) they call "rights." So far as I can tell, rights are like magic. You apply them to achieve a marvellous result. However, instead of a special word (presto), the magic is activated through a special understanding (I is sacred). So long as you and your audience both know it, the magic works. 
But the fourth and final movement that I witness is the most mystical to me. It seems that with each use, some of the rights-magic is sprinkled on the wielder, for before long rights are so deeply layered within the community's thought that members feel it's radical - irresponsible and even scary - to imagine other ways legal claims might work. If one person suggests: "I wonder if a less demanding approach of the other side might benefit us here," another says: "Well maybe for unimportant matters but not when it counts - and this counts," and still another states: "Who cares? They owe it to us."

With an ever-growing number of people thinking this way, a day comes when most members have forgotten that things could be different; the collective imagination has shrunk and the world holds less possibility. Rights have always been and couldn't be otherwise. To speak "law" means rights.

In such a world, trouble arises when this community encounters another with a different system of law, especially one in which legal claims aren't expressed as rights. In such encounters, instead of identifying the absence of law as they know it, and thus inquiring how, given the absence, the other community maintains order, it determines the absence of any law at all. From this stance, it assumes an obligation to export freedom for those who don't know they lack it. It turns out, however, that people don't enjoy having freedom forced upon them and the whole thing degenerates into permanent conflict kind of like the state of nature they left behind only now with much more stuff. More stuff and the rather uncomfortable revelation that only certain people are sacred; the rest don't need to decide for themselves. The part I can't figure is how they know which I's are the sacred ones. It seems the deciding factor is membership in the community, but hey, waitaminute, that upends the initi-

I'm pulled from this thought and my tikinaagan-like stillness by Talking Rabbit Manshape tapping my shoulder with a finger like a thumping foot and whispering in my ear "time to go, shushy." I climb once more on his back, but bothered. My final thought of this community as I dig into rabbit fur is that the social agreement to create a shared public sphere and thus to place boundaries on the private one has masked, not eliminated, the violence members fear and that serves as the cause for the whole social adventure. Ultimately, the agreement is about reorganizing the violence that fear grows. Episodes of violence occasionally punctuate the private side of the great divide, but the real demonstration is within governance.

The public sphere proves not to be a neutral space because it's populated by people and people, it turns out, aren't so good at leaving their individual beliefs and ideas at home. Many seem unaware of the inner workings of their judgment even as they claim, and perhaps sincerely intend, to live by the social agreement. But others don't appear even to try. They try to appear neutral, but really they're playing a game. The goal is to smuggle as much of one's own view into the public sphere as possible, all the while speaking, representing, and arguing as if one isn't doing so; as if one's goal is everyone's goal. The most successful winners of the game are those who make their particularity invisible to others, for without particularity one passes as the neutral space. At the hour of my leaving, those who are affluent, ablebodied, heterosexual, cys-gendered, white, and male are the winners.

I barely reach the period to that thought before I'm upupup once more (clinging first to rabbit back, then to rabbit foot, then to dear life) before a brief moment of blackness and then it's downdowndown SMACK into an unceremonious pile. I shake it off and when I straighten myself out, I behold a very different first scene from the last one. It's the same trees, lake, and river as last time, but the world they inhabit has changed. Gone are the disconnected, fearful individuals hiding, wandering, and brandishing weapons. No exodus from violence behind the tree line into the freedom and permanence of settlement. 
No state of ubiquitous violence to exit; no such bargain struck. And so gone, too, the sequence of community discussions through which the social arrangement slowly progresses towards its most perfect self.

In fact, the humans here aren't, and don't seem interested in, progressing towards anything. In their world, a day when they have it all figured out is a day never coming. They bend that line of progress until its end is affixed to its beginning. For them change happens in a circle.

Talking Rabbit Manshape blows little circles into the air. The smoke from his lips comes from a pipe he's puffing. Not an opwaagan, but a Sherlock Holmes pipe. He nods and tells me I'm on my way to solving the case of the two communities. I take that approval as permission to reboard my train of thought.

When one moves through an arc - knowing that forward is always eventually a return - one doesn't ask how to perfect the community; one asks how best to be part of the community that always already is. And it includes everyone, not just humans. Flyers, four-leggeds, crawlers, and swimmers are all moving through the hoop. And in their own ways, other beings called manidoog and aadizookaanag are too. All are connected.

"All connected - no rabbitism," Talking Rabbit Manshape expects askingly.

I pause for a moment. "No rabbitism," I announce with forced confidence, assuring him I understand. He nods and I continue my tikinaagan-like watching.

To be sure, there are distinct human communities with distinctly human interests and needs - just as there are distinct black bear and red pine communities. But these all function as particular locations within, not escapes from, the circle of earth community. As such, each (individuals and communities) strives to govern itself in ways that meet its needs but that always respects the needs of others moving through the circle, those who've already done so and those whose journey hasn't yet begun. Instead of perfecting community, humans join in the messiness.

So.

"So," says Talking Rabbit Manshape with momentary gravity and focus that dissipate as he gets distracted and squeals excitedly: "Hey look over there"! He points with his nose but because it's twitchy he singles out just about everywhere. Eventually he realizes and the nose settles. "It's called manoominikewin." 16

Skipping the in-between bits, this is what I see.

An old man in the bush cracks open a few bagaanag (hazelnuts), examining their ripeness. He then ambles to the water's edge, taking his time, and reaches out to the tall grass growing there. He takes several shafts between his fingers, feeling it and looking carefully at the husks. He nods and climbs back up the small hill to his wiigiwaam. He tells his middle-aged sons to get the ogimaa, their leader, while he speaks with his daughters. The ogimaa soon shows up and is offered a hot cup of tea, which he accepts. They chat and trade stories. Eventually, the old man mentions the grass. The ogimaa takes his time with the conversation and when his cup is empty, he leaves. The women take their canoes (jiimaanan) down to the water and set off into the shallows of the tall lake grass. They begin to tie the grasses into sheaves so that the jiiman laneways open up between them. Not long after, the community gathers, and the old

16 Much of the knowledge that serves as the basis for this section on manoominikewin comes from my own direct experience at Couchiching and Mitaanjigamiing, but most of it (including terms in anishinaabemowin) comes from teachings, shared over years, of an Elder who prefers not to be named. 
people offer prayers. The water levels have been constant and there's been lots of sun; it's been a good year and there's much food to harvest. These are no ordinary grasses; they're manoomin, wild rice.

The day comes when the first of the rice is ready. The old people thank all of the beings involved in offering this gift: the sun, lake, and the earth of the sky, water, and land worlds respectively for working together to give this life; the winds for staying calm as the grass grew; the ducks and muskrats for coming to feed here and offering many of their number to the humans and for transporting the seed to other places; to the manidoog of the area and to the aadizookaanag of the season; to manoominike-giizis (the moon this time of year); to the creator for having gifted manoomin to the people. The old people pray their gratitude with words and pipes and drums.

The families harvest in their separate areas, areas where they've been returning for countless years during this moon and, thus, where they have the strongest relationships with manoomin, the lake, the animals, and the spirits of the area. As each canoe sets off, its occupants leave a small amount of asema (tobacco) in the water and speak to the water and the manidoog that live there. Most of the canoes are occupied by a man and woman partnership, not because this is a social or economic ideal but because most rice camps are organized as family units. The man usually stands in the stern and uses a long, forked pole to slowly push the canoe forward. The fork at the end of the pole has little surface area and makes little impact on the lake bottom. The woman uses one cedar knocker to pull the rice sheaves over the gunwales and the other to strike the stalks (powi'am). The rice (and the inch worms that love them) from higher up the stalks falls into the canoe, slowly filling it and generating heat. Many fall into the lake, but the couple is pleased with this. They make many passes through the laneways the women have designed. They later return down the very same laneways as manoomin continues to ripen lower down its stalk throughout its season.

Back on land, the canoes are emptied onto birch bark and elm bark sheets. Manoomin is taken from here into a large pot angled over a low fire where it's stirred constantly. After about twenty minutes of this difficult, hot, and smoky labour, the rice is roasted (kaapizige) and dumped onto a different sheet, and the next batch of green rice is now brought into the parching pot. The roasted rice is spread over a large area and periodically turned over so that its heat will escape. Once the rice has cooled, someone places it in a hole dug into the earth two feet wide and a foot-and-a-half deep (bootaagan) and lined with a flat stone and then a mat or blanket. Someone - usually an older child - steps into the hole and leaning on two poles set in a v-shape for support, dances it (baawishkam) by twisting his feet. He puts on a new pair of moccasins for this dance. The dance separates most of the parched hulls from the kernel inside. The remaining hulls are separated in a birch bark winnowing basket (nooshkachige), often by women. These have a shallow lip so that as the rice is shook, the remaining hulls, being lighter than the kernels, are gingerly bounced over the edge. The rice is then meticulously cleaned: the last of the hulls, roasted worms, and detritus hand-sifted out. At last, the rice is ready to be boiled and prepared for eating!

But the most important part remains: the parents insist to the children that before any of the rice can be eaten, it must be feasted (wiikwaandiwin). The whole camp gathers for this celebration of thanksgiving. Ogimaa has given asema to one of the old people - a grandmother - to speak on behalf of the community.

"I can't even wait!" blurts Talking Rabbit Manshape, licking his lips. "I hope she's not one of those old people who takes too long." 
A special birch bark dish is brought to her by one of the young people, a helper of hers. This dish, along with a bundle of asema and a copper cup of water another woman has given her, is placed on a blanket in front of the grandmother and around which all are gathered. There's just a small amount of each of the foods brought to the gathering in this dish. Unlike the serving dishes and the individual dishes community members have brought, it has outside bark on the inside and inside bark on the outside. When everything has been carefully prepared, the grandmother picks up the dish and the asema, holds them lovingly, and speaks (almost with the first word, Talking Rabbit Manshape passes out). There are a great many beings to acknowledge and to thank, and so the grandmother does indeed speak for quite some time. All of the beings who help manoomin and the Anishinaabe are recognized and thanked. Any ancestors, manidoog and aadizookaanag, who may be present are also welcomed to the feast. The gist of the rest of it, as I understand it, roughly breaks down to this: "Manoomin, we honour you. We love you. We are so grateful for your gift. For your medicine. How you heal us and feed us and help us grow in a good way. How you will help us through biboon, that long winter season. How you give us good lives."

"Manoomin, we are grateful to be Anishinaabe, for having young ones to learn to care for you so we can keep being Anishinaabeg. We offer you this spirit dish, and we pray on this asema to show our gratitude for you, to keep our relationship strong for next year and for those ones still to come. This is what we were taught to do, by the gete-anishinaabeg, to honour you, and we listen to our teachers. We remember our dreams. We follow nitam gikinoo'amaagewinan, our original instructions, to be responsible, to take care of all our relations. ${ }^{17}$

"For all of this, we say gichi-miigwech, loving thanks," and she repeats the word to the four directions. And with that, the community members begin to fill their own bowls, the younger folks doing so for the old ones. There are lots of laughs, stories, and teasing after all that hard work. As the community enjoys itself, I get to thinking about some of the additional threads woven into the community fabric that is manoominikewin, the making of wild rice.

The ricers harvested what they needed, but at season's end most of the rice remains on the stalks. As the community packs up camp, ducks and muskrats feast and frolic in the waters.

The grandmother thanked the cedar tree for offering wood that is so light. When carved into knockers, it doesn't break the rice stalks. She thanked the birch, balsam, and diamond willow for their contributions to the winnowing basket.

All of the uneaten food that couldn't be saved was placed in the fire. Same with the spirit dish with the inverted bark: it was placed in the fire with its assema.

I'll need to think for a long time about what I witnessed here and how things worked.

About what wasn't here and why.

About what manner of higher law directs these people and how, in the absence of formal rules governing interaction, they behave responsibly, know what to do, and coordinate the gifts of one with the needs of another.

17 Readers wanting to better understand the ideas presented in these paragraphs may be interested in Oshoshko Bineshiikwe - Blue Thunderbird Woman et al, "Ogichi Tibakonigaywin, Kihche Othasowewin, Tako Wakan: The Great Binding Law", online: <http://www.turtlelodge.org/wp-content/uploads/2015/11/ScrollBanner_TheGreatBindingLaw_24x36-PROOFv03.pdf>. 
"Good wonder," nods Talking Rabbit Manshape. "Let's find out." I close my eyes, trying to force the nosy rabbit out from behind them. When I open them, the scene has changed.

I'm following a small boy on fast forward, almost visibly aging in front of me. I observe the processes and institutions that instill in him an understanding of what healthy relationships look like and how to reason for himself when adjustments are required. At first the boy is a baby wrapped tight in his tikinaagan (a cradleboard), from which his inquisitive mind absorbs the world. From his moss bag, he learns to watch and listen before speaking or acting. This is an early, but vital, part of how the boy learns about relationships. He's never put down to sleep during the day; when he tires of learning he puts himself to sleep by playing with the painted turtle shoulder blades that hang from his retaining bar.

The old people in the community, while never venerated, are given a profound respect for their role. They instruct the small boy, his parents, and the community as a whole when it gathers to address challenges and make decisions. But the instruction is rarely corrective; the boy's given tremendous freedom to make and learn from mistakes and so to reform his own behaviour. Even in ceremony he wanders freely about the lodge. As the boy gets a little older, he learns much from being and working alongside adults, as they chat among themselves and share why they do things a certain way.

Storytelling is a vital institution too. Different kinds of stories meet different needs. One kind of story called aadizookaanan plays a very significant role in shaping the boy's understanding of what it means to have healthy relationships and how his responsibilities shift both across them and within them, as time and place change. These stories are often ambiguous and after a night of listening, the boy is frequently as confused as he is enthralled. Aadizookaanan require him to reason through answers for himself. In time, this training empowers him to effectively manage circumstances he encounters which aren't presented in the stories. As he labours, watches, and listens, considerable insight is also taken from another kind of story - dibaajimowinan - which encode community, family, and eventually his own knowledge of past experiences. In hearing these stories transmitted forward, he benefits from his ancestors' vast experience. He learns what they did and why; why his community has good relationships with some communities and not others; what things, clever and foolish, that chiefs, medicine people, strangers, and boys just like him have done in times past.

The boy also spends considerable time learning from the earth and the myriad animal, plant, and spirit persons around them. He takes lessons from what he witnesses in these behaviours and relationships, akinoomaagewin, ${ }^{18}$ and reasons about their meanings for his own life. One of his most significant land-learning experiences is gii 'igoshimo, when he fasts for a vision. He's put out in the bush to fast when his voice begins to change and his father feels he's ready. The first year nothing happens for this boy. The second year he goes for six days without eating or drinking before his vision comes to him. He has to be carried home, and his father couldn't be more proud of his son's accomplishment. He's a man now: he has unique medicine power and understands his purpose. He can lead a full life for himself and be of much help to others.

As a young man, much of his tacit understanding of how to have good relationships comes from his increasing role in ceremony, as he learns songs and dances (he has dreamed of a drum) and better understands the manidoog and aadizookaanan moving in and out of his journey. A lifetime of honouring

18 For those who want to know more about this, John Borrows explains this concept in his article in this volume: John Borrows, "Outsider Education: Indigenous Law and Land-Based Learning" (2016) 33:1 Windsor YB Access Just at 1. 
those from whom he's received gifts and of gifting others has oriented his heart in a particular way. Expecting nothing, he embodies an ethos of gratitude for all that creation gives him: miinigowiziwin.

As I have this culminating realization, you-know-who pipes up. "Well," says Talking Rabbit Manshape, placing one paw on my shoulder: "I thought that was a pretty good show." He nods his head slowly, soaking in his own comment. "How do you feel?"

"Full. I feel full."

"I've heard about full," he says, "but never had it. Usually I feel like more."

My eyes pop like corn. "I think I had better not," I offer, stunned at the prospect.

"Ah. All good things, eh? Well. I hope this was helpful. With understanding your community." Ah, yes, my community.

"Guess we'll see." It's a statement filled with nothing because my brain's full of everything. I'd like it if those hollow words could complete my answer, but in the absence that follows I hear unwelcome irony. "But thanks," I add. "I sure appreciate it." Talking Rabbit Manshape once more steps up on my toes, but this time he just holds me. And with my addendum, I seem to have concluded the adventure: my host dismounts my feet, places all paws to earth and readies himself for lift-off.

From up on his back, I take a last look at this world, so different from the other, and wonder how I'll ever manage to steer through their collision in my own. And that's it. Before the next thought, it's upupup, black, downdowndown, dot-waving arm-nokomis, SMACK.

There's nokomis a few feet from me, waiting in the shotgun seat of my car. The first few drops of rain mark the windshield. She crosses her arms in stern disproval of my helmet, snapped in half and hanging off one ear. I look across Gaamitigomishkag and notice the same trees, lake, and river I saw in the other two worlds. The wind has caught my shirt again. I look for Talking Rabbit Manshape and find a snow-white rabbit hopping wildly behind me, grabbing chunks of grass as he goes. Feeling my gaze, he turns momentarily and that erstwhile twitchy nose marks me like an arrow. I reply weakly, turning the unasked question on him but he doesn't answer. He just keeps hopping as he slowly converges on the distance, a little bit everywhere, possibly in the crude arc of a circle.

I take one last look around, marking all that's here before opening the car door.

"Come on over to my house," nokomis says. "I need help with something."

I join hands to wheel and smile through the glass. 